\title{
Nuclear Policy in Equation of Power Balance
}

\author{
Florian Rapan \\ "Dimitrie Cantemir" Christian University, Bucharest, Romania, rapan_florian@yahoo.com
}

\begin{abstract}
After the end of the Cold War, it was attempted to create the appropriate framework for progress in armaments control and disarmament. Although there have been fundamental changes in international relations and the security environment, efforts and initiatives in the field have proved to be often free from obstacles and disagreements. One reason for this is due to the increase in the number of states involved in the negotiations and, implicitly, the multiplication of political, economic and security interests. The logic of the bipolar world and nuclear deterrence, characteristic of the Cold War, did not take into account the security aspirations of other state actors. Currently, nuclear weapons, although necessitating an internationally sustained dialogue, raise issues that make it difficult to cooperate in this area. Owners cannot be subjected to collective sanction. Theoretically, they have great freedom of action, which can ultimately be restrained only by other nuclear powers. In addition, the idea of an anti-missile shield is increasingly being discussed, but in the absence of bilateral or multilateral agreements limiting the number and location of ballistic interceptors that can be placed by different states.
\end{abstract}

KEYWORDS: disarmament, international cooperation, nuclear hazard, nuclear weapons, political decisions

\section{Introduction}

The theme of nuclear proliferation, especially in its current dimension, as well as debates on agreements and treaties in force, are present both on the international agenda and at the level of studies and analyses. Lately, there has even been a particular emphasis on these concerns from international events. Recent developments in the beginning of 2019, such as the suspension by the US of the Intermediate-Range Nuclear Forces (INF) Treaty obligations, the subsequent reactions of the Russian Federation to this situation and the anti-missile shield in Europe, as well as the diplomatic failure of the Vietnam Summit, at the end of this February, without reaching a nuclear agreement between presidents Donald Trump and Kim Jong-Un, demonstrates that nuclear safety risks in the international arena are high. All of these points reveal that states having nuclear capabilities are not ready to give up their arsenals in the near future.

\section{Nuclear issues from the perspective of international relations}

Nuclear weapons are given an increasingly important role in the security and defense strategies and doctrines of the great powers. In parallel, international treaties in the field not only show the recognized deficiencies, but also constitute concerns for international relations. The United States suspension of obligations underwritten by the Intermediate-Range Nuclear Forces (INF), signed with Russia in 1987 (Arms Control Association, 2019), President Donald Trump's decision to withdraw the US from the nuclear agreement with Iran, the ambiguous position of the Washington Administration towards the development of North Korea's nuclear arsenal are the latest examples. Including during the $55^{\text {th }}$ Munich Security Conference on 15-17 February 2019, where heads of state and governments, ministers and international relations experts highlighted several asymmetries between the US and Europe in a series of global issues, one of which involves keeping the Iranian nuclear treaty. There is some skepticism that a consensus can be reached on the amendment of existing international nuclear treaties or the design of new ones that have effects in terms of reducing the proliferation of nuclear weapons. International cooperation, being the main means of reducing one of the most dangerous threats in recent years, has to remove significant obstacles before concrete results are reached.

Since the early 1990s, nuclear weapons concerns have essentially been related to nonproliferation cooperation, to the conservation of the former Soviet arsenal, or to the prevention of regional nuclear weapons dissemination. In spite of international cooperation efforts aimed at curbing proliferation, and of significant measures to reduce the world arsenal, nowadays, thousands of nuclear weapons are held by the US, Russia, China, France, Israel, the United Kingdom, India, Pakistan, and, more recently, North Korea and Iran. In addition, following the waiver of some of the 
nuclear arms deals negotiated in recent years, the US has been criticized for sending out contradictory signals to North Korea, Iran and other nations that have the technical knowledge needed to produce nuclear weapons.

There are seven confirmed nuclear powers in the world (in other words, they have publicly tested nuclear weapons: the United States, Russia, China, Britain, France, India and Pakistan.) To these add another three: Israel allegedly holds about 300 nuclear warheads, North Korea - about which there is no confirmation, apart from their own contradictory statements and Iran - for which the latest report of the International Atomic Energy Agency (IAEA) indicates that it intends to use atomic energy in military purposes (IAEA, Annual Report 2017). Among the last three, only Israel and North Korea have consistently refused to sign the Nuclear Non-Proliferation Treaty. By signing the Treaty, Iran is monitored and inspected, hence the frustrating statements of Tehran leaders who believe they cannot hide anything, and the conclusion that they would enrich uranium for purposes other than peaceful is inconsistent with reality.

Another fundamental dimension of proliferation is that although global powers gradually diminish their nuclear weapons depots, they all develop new missiles and warheads that could escalate the risk of atomic confrontation. Thus, the bigger number of nations that have nuclear weapons increases the risk of using such means. Today, unlike the Cold War period when nuclear weapons were considered a threat, states are beginning to consider their use.

Currently, the main concern of the five major nuclear powers (the United States, Russia, China, the UK, and France) is that some countries considered by the United States to be part of the Axis of the Evil (concept launched by the George W. Bush Administration in the summer 2001) not to be equipped with atomic weapons. For many years, they have been trying to discourage North Korea and Iran, alternating promises and threats, whose success has been uneven over the last few years. On the other hand, the incriminated states believe that the Treaty on the Non-Proliferation of Nuclear Weapons (NPT) guarantees the inalienable right of everyone to develop nuclear technologies for peaceful purposes. Under these conditions, it is not acceptable that the development of such technologies belong only to countries that hold nuclear monopoly and who use the pretext of non-proliferation, which violates the treaty provisions and constitutes an act of discrimination. The real threat comes from non-party states that should be supervised, as they have unrestricted access to nuclear material, technology, and equipment, while states participating in the treaty are subject to limitations and restrictions. Several years ago, it was even said that a future non-proliferation treaty should ban the doctrine of using nuclear weapons against states that do not hold nuclear weapons, a position backed by the US and NATO (Kamal Kharrazi, former Iranian Foreign Minister, 2005).

Another issue that arises is to be able to distinguish between civilian and military nuclear programs. At present, this issue is not solved and is found in an ideological plan at the level of intentions. This raises the question of how effective disarmament is in a world where dual-use technologies bear the civilian label. Modalities are being sought (market mechanisms, international fuel banks) to ensure that states that have civilian nuclear reactors can receive fuel without having to produce it. Reactors that prevent proliferation are considered of the next generation, being in the project stage. According to this way of thinking, the difficulty in analyzing and quantifying, lies not only in the civil-military binomial, but also in the problem of rational attitude. At present, the nuclear balance is based on the assumption that states involved in nuclear programs have secure capabilities and adopt a rational attitude, the danger being generated only by pariah states. Another tendency is also to bring into use older concepts of use during the Cold War period. Thus, the doctrine of mutually assured destruction has not only lost its sense of being, but has also multiplied, functioning at the level of regional security. Nuclear weapons and the concept of mutually assured destruction are considered to have prevented the Cold War from turning into a global conflagration. In 1962, the US and Russia faced the Cuban Missile Crisis directly, but withdrew before the outbreak of a nuclear war over fears that they could destroy each other, a situation that led to the theory that nuclear weapons could have a positive role for international stability. 
At present, it can be considered that, beyond the other factors involved, the nuclear parity between India and Pakistan has led to the best relations between the two countries after the Second World War. As a result, despite the proliferation of nuclear weapons, it may be concluded that, depending on the circumstances, a nuclear power can increase and not reduce stability in the region. Another example could be linked to the Middle East, where Israel is a nuclear power which, in the absence of a nuclear arsenal-holding adversary, could be tempted to use nuclear weapons as a first choice means of its military capability.

Removing the nuclear threat involves clearly defined requirements: limiting and even eliminating existing weapons, halting the proliferation and spread of nuclear weapons, and adopting measures to prevent modernization of the existing ones. The security environment has evolved since 1990 in the sense of increasing complexity and interdependence in international relations. International stability is conceived today on the basis of multi-level cooperation at the international community level. Greater dialogue is required in an institutionalized setting by increasing the involvement of major international organizations in defining the world's nuclear security.

\section{Negotiations, treaties and agreements in the nuclear field}

Opposing the realistic balance of power conception, the philosophical foundations of liberalism are cooperation and development within international organizations as an instrument of peace-building at the international level, which needs to be sustained through a disarmament policy. The topic of cooperation is present in neoliberal theories, being facilitated by the existence of international institutions that have to issue a set of legal rules, norms, practices and principles, as well as institutions for their application: treaties, resolutions of the Security Council, individual state declarations, memoranda, international conventions. At present, verification of compliance is achieved through international organizations or through states parties. (UNODA 2019). The main international body in the field is the International Atomic Energy Agency (IAEA), an organization subordinated to the United Nations and, in particular, to the Security Council. The IAEA is an international organization created in 1957, whose main task is to contribute to the development and practical use of atomic energy for peaceful purposes and to the development of scientific research in this field and currently counts 151 member countries. The European Atomic Energy Community (EURATOM) is an international organization for the peaceful use of atomic energy, set up in 1957 to develop nuclear energy in Western Europe and to control the use of nuclear materials. Between EURATOM and the IAEA, there is an agreement for joint application of safeguards and control in EU countries. Over time, other international bodies have played an important role in the field, but for short periods of time or limited objectives (eg the Arms Control Agency created in 1954 under the Brussels Treaty and subsequently abolished).

In 1946, based on the principles of the US-Canada High-Level Declaration, Canada, the United Kingdom proposed to the UN the creation of an international body responsible for the management and control of nuclear issues. In fact, one year before, they acknowledged that the nuclear monopoly could not be maintained and stressed the importance of preventing the proliferation and encouragement of peaceful applications of nuclear energy. On this basis, the United States Government (along with Canada and the United Kingdom) initiated the Baruch Plan and advanced it to the United Nations Atomic Energy Commission (UNAEC). This plan provided that all states should cease production of atomic weapons and submit production-related documentation to the United Nations Atomic Energy Commission (UNAEC). It aimed at "fully transferring the right of ownership and control over nuclear energy sources to the competence of an international body and transferring US stocks to the same international body" (Calvocoressi 2000, 33). The Soviet Union did not want to accept this plan, insinuating that, in this way, the United States would have nuclear monopoly. In reply, the USSR formulated their own proposals to ban nuclear weapons. In fact, both disarmament plans contained irreconcilable formulations. The American version referred to the idea of international property rights, and the Soviet one to the destruction of existing weapons stocks, which was rejected by the Americans, the only nuclear weapons possessors at that time. On this essential ground, the negotiations entered into a deadlock, then tacitly giving up the Baruch Plan. It is believed that its collapse led to the beginning of the 
Cold War army race. Once the danger of proliferation became clear - in 1949 the USSR detonated the atomic bomb and the United Kingdom in 1952 - the US President, Dwight D. Eisenhower, advanced in 1953, at the UN General Assembly, the Atoms for Peace Initiative.

On August 5, 1963, the USSR, the United Kingdom, and the United States sign the Partial Test Ban Treaty (PTBT), which entered into force on 10 October 1963 and was subsequently ratified by 123 states. The treaty was drafted and adopted in order to reduce the arms race and to stop the excessive testing of nuclear weapons, increasing the level of radioactive contamination at ground level, in the atmosphere and in the underwater environment. However, it has failed to stop proliferation, given two main causes. The first is because it did not contain verification mechanisms, and the second because underground experiments were exempted, which allowed both the US and the USSR to further refine their arsenals through tests conducted in an environment difficult to detect at the time. From a political point of view, the Treaty established the first great success of the disarmament partisans, marking the victory over the resistance of the followers of an arms race free from any restrictions, and also contributed to the consolidation of the international detente climate (Istrate 2005,4 ). The treaty constituted a preamble to the conclusion of the Treaty on the Non-Proliferation of Nuclear Weapons (NPT).

The Treaty on the Non-Proliferation of Nuclear Weapons (NPT) was initiated on July 1, 1968 and effectively entered into force on March 5, 1970, with its ratification by Britain, the USSR and the US, along with other states. The Treaty recognizes two categories of states: non-nuclear-weapon states and nuclear-weapon states - US, UK, France, Russia and the PRC - respectively the 5 winning powers in the Second World War and also Permanent Members with veto rights in the UN Security Council. The treaty is also important by stipulating the obligation of non-nuclear-weapon states to accept IAEA safeguards (control).

Both treaties, the PTBT and the NPT, allowed the transition to a US-USSR bilateral approach to the problems posed by the accumulation of strategic armaments determined by the arms race. As a result, the negotiations started in Helsinki in 1969 ended with the signing on May 26, 1972, in Moscow, of two important treaties. One is the Strategic Arms Limitation Talks I, which noted the parties' agreement on setting of the maximum limits for strategic nuclear weapons (intercontinental ballistic missiles based on ground and submarines as well as strategic submarines) at the operational and construction site since the signing of the agreement. Under the SALT I Treaty, the two great powers also commit themselves to no longer manufacture strategic nuclear weapons for 5 years and not to build land-based landing ramps. The other bilateral agreement, the Antiballistic Missile Treaty, signed on May 26, 1972, entered into force on October 3, 1972, and represented a form of balance that deterred the execution of the first nuclear strike. The Treaty does not prohibit the development of anti-missile systems, but merely limits their operationalization. Under the terms of the treaty, neither party is allowed to build a national anti-ballistic system. Only two regional systems were authorized, one to defend the capital, and the other, a region at choice. An additional protocol, signed in 1974, reduced the number of locations to one, but raised the ceiling of the offer to 100 interceptors and 100 launching facilities. The Soviets decided to protect their capital, and the Americans placed interceptors around the intercontinental ballistic missile launch facility at Grand Forks (North Dakota). Significantly, in the same year, the IAEA launches the first agreement for regional technical cooperation in the nuclear field, namely the Regional Cooperative Agreement for Asia and the Pacific. On June 18, 1979, President Jimmy Carter and Leonid Brezhnev signed the SALT II Treaty as a complement to the first agreement and the precursor to a SALT III nuclear missile agreement in Europe. Negotiations on this last deal have been postponed. After the Soviet invasion of Afghanistan (1979-1989), bilateral relations deteriorate, treaties are no longer ratified, but are rigorously respected by Moscow and Washington.

On March 23, 1983, Ronald Regan launched the Strategic Defense Initiative (SDI), which distinguished between offensive and defensive nuclear weapons, and planned to deploy spacecraft in order to destroy the intercontinental ballistic missiles launched by the enemy. The initiative is also known as "Star wars". In the official launch speech of the Initiative, President Reagan expressed his intention to initiate a global missile defense, space-based Maginot line, based on space satellites and lasers, capable of intercepting any type of intercontinental ballistic missile nuclear cargo coming from 
the Soviet Union (Kissinger 2003, 677). Three years later (January 1986) Mikhail Gorbachev, he formulated the proposal for the complete elimination of atomic weapons, not accepted by the United States. But in the same year (September 1986), 35 states sign the Stockholm agreements, which establish mutual control of military equipment and activities in the field.

The Intermediate-Range Nuclear Forces Treaty (INF) was signed on December 8, 1987 in Washington, marking an important moment in the evolution of the Cold War, but it also has a major impact on the evolution of the international relations of the world today. It provides for the reduction of a whole class of nuclear weapons: ballistic missiles and cruise missiles ranging from 500 to $5,500 \mathrm{~km}$. It has an unlimited validity period and allows both parties to carry out verification inspections at the military facilities of the other party. The treaty was politically considered to be one of the starting points of the end of the Cold War. It involved the physical elimination of all SS20 Soviet missiles directed against Western Europe and all Pershing II and Cruise missiles in NATO countries and aimed at the USSR. But, as already mentioned, the deal is currently in deadlock, both the US and Russia having recently decreed, at the highest level, to withdraw from this agreement, accusing each other of systematically breaches of the treaty.

\section{The current situation and the prospect of promoting cooperation in international relations}

Nuclear weapons are the most dangerous products of military arsenals. Their destructive capacity is immense, ranging from entire cities with millions of inhabitants to the natural environment with catastrophic, long-term effects for the evolution of living beings, for the atmosphere, temperature, light, landscape, water, soil, etc. The effects of using such weapons at war have been demonstrated twice in history, by the bombing of the two Japanese cities of Hiroshima and Nagasaki in August 1945. Some reports say the number of victims is between 129,000 and 240,000 or even more (United Nations Office for Disarmament Affairs (UNODA 2019). Half of the victims were registered only on the first day, and the other half during the months and years ahead. And let's not forget that in 1945 the destructive capacity was different from that of today's nuclear weapons and no one knew whether they had an impact on the environment or on the population.

In a study by the Stockholm International Peace Research Institute (SIPRI) published in July 2017, the 9 nuclear states had a total of 4150 deployable operational nuclear weapons at the beginning of the year (see Table 1). If one counts all warheads held (in reserve or in the course of withdrawal) it would total 14,935 , compared to 15,395 that were quantified in 2016. The reduction is, however, apparent. Nuclear powers reduce their nuclear arsenal on the one hand, but on the other hand, they modernize their nuclear capabilities in the context of increased investment in such weapons, according to the SIPRI report released in July 2017. Both the US, as well as Russia, who still possess $93 \%$ of the world's nuclear arsenal, are investing large sums of money to modernize it (SIPRI 2019).

Table 1. World nuclear forces, 2017

\begin{tabular}{|l|l|l|l|l|}
\hline Country & $\begin{array}{l}\text { Year of first } \\
\text { nuclear test }\end{array}$ & Deployed warheads* & Other warheads & Total 2017 \\
\hline USA & 1945 & 1,800 & 5,000 & 6,800 \\
\hline Russia & 1949 & 1,950 & 5,050 & 7,000 \\
\hline UK & 1952 & 120 & 95 & 215 \\
\hline France & 1960 & 280 & 20 & 300 \\
\hline China & 1964 & & 270 & 270 \\
\hline India & 1974 & & $120-130$ & $120-130$ \\
\hline Pakistan & 1998 & & $130-140$ & $130-140$ \\
\hline Israel & $\ldots$ & & 80 & 80 \\
\hline North Korea & 2006 & & $10-20$ & $10-20$ \\
\hline Total & & $\mathbf{4 , 1 5 0}$ & $\mathbf{1 0 , 7 8 5}$ & $\mathbf{1 4 , 9 3 5}$ \\
\hline
\end{tabular}

Source: SIPRI: Global nuclear weapons: Modernization remains the priority, 3 July 2017 
Nuclear weapons, although requires an internationally-sustained dialogue, raises issues that make difficult cooperation in this area, allowing nuclear states to escape collective sanctions. Theoretically, a state that possesses such powerful tools in its own arsenal, has great freedom of action, and it can be limited and ultimately embedded only by other nuclear powers.

In the same register, efforts to stop proliferation during the Cold War also include the creation of free zones of nuclear weapons. The Soviet Union first introduced the idea in Central Europe to the UN General Assembly in 1956. This initiative meant for Europe, as well as the following ones, were not put in practice. The first successful initiative to establish a free zone of nuclear weapons originated in Latin America amid the 1962 missile crisis. Nuclear tests were also a catalyst for another free zone in the South Pacific. The proposal was made by New Zealand in 1975 at the regional forum of this area. A Free Nuclear Weapon Area is a regional arrangement that prohibits the development, manufacture, stockpiling of the acquisition, possession of any explosive nuclear devices within the area of application by any contracting party. Applications for the peaceful use of nuclear energy are usually allowed subject to the application of IEA safeguards (control). As geographic areas that are completely free of nuclear weapons, free areas are recognized as important international nuclear non-proliferation and disarmament tools and represent a step towards a nuclear-free world. The denuclearised area was considered as a transitional measure of limiting the nuclear threat, which integrates into a system of measures aimed at preventing the proliferation of nuclear weapons, stopping the nuclear arms race and removing them from the arsenal of states. (Ionescu, 183).

A concept in the theory of international relations that takes into account the relationships between political entities is that of a security community that designates a group of actors who are genuinely convinced that the members of the community will not fight with each other, but will resolve their differences in a peaceful and differentiated way. Nuclear weapons have been part of NATO's collective defense policy since its inception. In the defense doctrine of November 1949, reference was made to the Alliance's ability to execute strategic bombings with this type of weaponry. Responsibility in this context was granted to the United States, which, as far as possible, had to be assisted by other nations. In 1999, NATO adopted a Strategic Concept based on a new set of principles. Indeed, since the early 1990s, NATO's nuclear policy has undergone a process of adaptation to the new security context (NATO Handbook 2006, 18-19). This has also been translated into significant reductions in nuclear capabilities (located in Europe) and in promoting measures to increase confidence and security with Russia. NATO's nuclear policy is based on respect for the Nuclear Non-Proliferation Treaty, considered by NATO members as the cornerstone of the international nuclear non-proliferation regime. All Allies are members of the NPT and support the universalization, observance and full implementation of the treaty, as well as other relevant international instruments in the field.

Europe's anti-missile defense program (ABM), would include the possibility of cooperating with Russia on the issue of reducing the nuclear arsenal, re-establishing the relationship by reviving bilateral and strategic arms control. US President Donald Trump presented his new missile defense strategy on January 17, 2019 to respond to the threats posed by the new armies of Russia and China, as well as Iran and North Korea. The new strategy, which replaces a 2010 document focusing on intercontinental missiles, provides for the development of weapons to counter the threat of cruise missiles. The new US anti-missile strategy has only increased tensions worldwide. In this context, Russian President Vladimir Putin assessed on 20 February 2019 the state of the Russian nation as part of the traditional annual message to the Russian Federal Assembly. He stressed that Moscow is aware of the development of the global anti-missile system. Russia, said President Putin, is forced to create and deploy weapons that can be used not only against those territorial locations from which the direct military threats emerge (here were stressed as targets the locations in Romania and Poland), but also against those "decision-making centers on the use of missile systems that threaten us". It follows that the options for the role of nuclear weapons and their presence on the territory of some European countries, as well as the role and evolution of anti-missile defense systems remain to be clarified, given the recent expression of different positions in relation to these issues, both at 
the level of the two great powers and at NATO level. This is because the Russian Federation has repeatedly replied to NATO's decisions, bringing about nuclear arguments.

\section{Conclusions}

The logic of the bipolar world and the nuclear deterrence, characteristic of the Cold War, did not take into account the security aspirations of other state actors. Paradoxically, the prolonged confrontation between the US and the USSR has created a world in which other states, less involved in this game, have refused to accept the guarantees offered by either of the two powers, opting to obtain their own nuclear capability, aiming to address their concerns about security vulnerabilities. Neither the influence of the two superpowers nor the international security mechanisms have been able to prevent the proliferation of nuclear weapons and carrier vectors. There are, however, significant differences between the motivations of each of the states owning or aspiring to possess nuclear military capabilities.

The only solution to avoid the nuclear arms race is international co-operation through engagement in general arms control negotiations, in negotiations that lead to the regulation of the field through information exchange and the limitation of nuclear capabilities that may pose threats to one state or another.

\section{References}

Arms Control Association. “The Intermediate-Range Nuclear Forces (INF) Treaty at a Glance”. Accessed March 4, 2019. https://www.armscontrol.org/factsheets/INFtreaty.

Istrate, Cristian. 2005. Dreptul dezarmării. Acorduri multilaterale. Bucureşti. Editura All Beck.

Kissinger, Henry, 2003. Diplomaţia. Bucureşti. Editura All.

Ionescu, Ovidiu. 1978. Dezarmarea si noua ordine internatională. Bucureşti. Editura Politică.

International Atomic Energy Agency (IAEA). “Annual Report 2017”. Accessed March 4, 2019. www.iaea.org/sites/default/files/publications/reports/2017/gc62-3.pdf.

Kharrazi, Kamal, former Iranian Foreign Minister. Iran vows to pursue nuke technology. 2005 UN Conference on NonProliferation of Nuclear Weapons. CNN International. Accessed March 4, 2019. http://edition.cnn.com/2005/WORLD/meast/05/03/iran.nuclear/index.html.

NATO Handbook 2006. Public Diplomacy Division NATO 1110 Brussels, Belgium.

Calvocoressi, Peter. 2000. Politica Mondială după 1945. Bucureşti. Editura Alffa.

The Stockholm International Peace Research Institute (SIPRI). 2019. "Global nuclear weapons: Modernization remains the priority". Accessed March 4, 2019. https://www.sipri.org/sites/default/files/styles/node/public/201707/nuclear_forces_2017_pie_chart_0.jpg ?itok=XfjnOeOY.

United Nations Office for Disarmament Affairs (UNODA). 2019. "Nuclear Weapons". Accessed March 4, 2019. https://www.un.org/disarmament/wmd/nuclear/. 